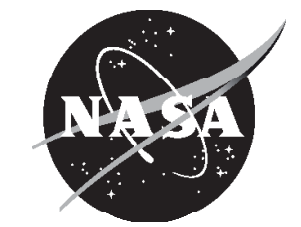

\title{
Investigation of Liquid Metal Heat Exchanger Designs for Fission Surface Power
}

Rodger W. Dyson, Barry Penswick, Malcolm Robbie, and Steven M. Geng Glenn Research Center, Cleveland, Ohio 


\section{NASA STI Program . . . in Profile}

Since its founding, NASA has been dedicated to the advancement of aeronautics and space science. The NASA Scientific and Technical Information (STI) program plays a key part in helping NASA maintain this important role.

The NASA STI Program operates under the auspices of the Agency Chief Information Officer. It collects, organizes, provides for archiving, and disseminates NASA's STI. The NASA STI program provides access to the NASA Aeronautics and Space Database and its public interface, the NASA Technical Reports Server, thus providing one of the largest collections of aeronautical and space science STI in the world. Results are published in both non-NASA channels and by NASA in the NASA STI Report Series, which includes the following report types:

- TECHNICAL PUBLICATION. Reports of completed research or a major significant phase of research that present the results of NASA programs and include extensive data or theoretical analysis. Includes compilations of significant scientific and technical data and information deemed to be of continuing reference value. NASA counterpart of peer-reviewed formal professional papers but has less stringent limitations on manuscript length and extent of graphic presentations.

- TECHNICAL MEMORANDUM. Scientific and technical findings that are preliminary or of specialized interest, e.g., quick release reports, working papers, and bibliographies that contain minimal annotation. Does not contain extensive analysis.

- CONTRACTOR REPORT. Scientific and technical findings by NASA-sponsored contractors and grantees.

- CONFERENCE PUBLICATION. Collected papers from scientific and technical conferences, symposia, seminars, or other meetings sponsored or cosponsored by NASA.

- SPECIAL PUBLICATION. Scientific, technical, or historical information from NASA programs, projects, and missions, often concerned with subjects having substantial public interest.

- TECHNICAL TRANSLATION. Englishlanguage translations of foreign scientific and technical material pertinent to NASA's mission.

Specialized services also include creating custom thesauri, building customized databases, organizing and publishing research results.

For more information about the NASA STI program, see the following:

- Access the NASA STI program home page at http://www.sti.nasa.gov

- E-mail your question via the Internet to help@ sti.nasa.gov

- Fax your question to the NASA STI Help Desk at 301-621-0134

- Telephone the NASA STI Help Desk at 301-621-0390

- Write to: NASA Center for AeroSpace Information (CASI) 7115 Standard Drive Hanover, MD 21076-1320 
NASA/TM-2009-215505

AIAA-2008-5733

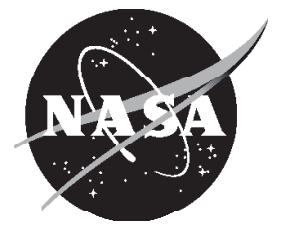

\section{Investigation of Liquid Metal Heat Exchanger Designs for Fission Surface Power}

Rodger W. Dyson, Barry Penswick, Malcolm Robbie, and Steven M. Geng Glenn Research Center, Cleveland, Ohio

Prepared for the

Sixth International Energy Conversion Engineering Conference (IECEC)

sponsored by the American Institute of Aeronautics and Astronautics

Cleveland, Ohio, July 28-30, 2008

National Aeronautics and

Space Administration

Glenn Research Center

Cleveland, Ohio 44135 
This report is a formal draft or working paper, intended to solicit comments and ideas from a technical peer group.

This report contains preliminary findings, subject to revision as analysis proceeds.

Level of Review: This material has been technically reviewed by technical management.

Available from

NASA Center for Aerospace Information 7115 Standard Drive

Hanover, MD 21076-1320
National Technical Information Service 5285 Port Royal Road Springfield, VA 22161

Available electronically at http://gltrs.grc.nasa.gov 


\title{
Investigation of Liquid Metal Heat Exchanger Designs for Fission Surface Power
}

\author{
Rodger W. Dyson, Barry Penswick, Malcolm Robbie, Steven M. Geng \\ National Aeronautics and Space Administration \\ Glenn Research Center \\ Cleveland, Ohio 44135
}

\begin{abstract}
Fission surface power is an option for future Moon and Mars surface missions. High power nuclear reactor heated Stirling convertors are an option to provide reliable power for long duration outpost operations. This report investigates various design approaches for the liquid metal to acceptor heat exchange and clarifies the details used in the analysis.
\end{abstract}

\section{Nomenclature}

$\Delta T \quad$ Difference in Temperature between solid surface and surrounding film area, $K$

$\dot{m} \quad$ Mass Flow Rate, $\mathrm{kg} \mathrm{s}^{-1}$

$\mu \quad$ Water Viscosity, $\mathrm{kg} \mathrm{m}^{-1} \mathrm{~s}^{-1}$

A Outside Solid-Fluid Contact Surface Area, $m^{2}$

$A_{c} \quad$ Cross-sectional Area of Flow, $m^{2}$

$C_{p} \quad$ Heat Capacity at Constant Pressure, $\mathrm{Jmol}^{-1} \mathrm{~K}^{-1}$

$d_{h} \quad$ Hydraulic Diameter, $m$

$h \quad$ Overall Heat Transfer Coefficient, $\frac{W}{m^{2} K}$

$k_{w} \quad$ Thermal Conductivity of Water, $W m^{-1} K^{-1}$

$\operatorname{Pr} \quad$ Prandtl Number, $\frac{C_{p} \cdot \mu}{k_{w}}$

$Q \quad$ Power input or heat lost, $W$

$q_{i} \quad$ Heat Flux from the Wall, $W m^{-2}$

Re Reynolds Number, $\frac{\dot{m} \cdot D_{H}}{\mu \cdot A_{c}}$

\section{Introduction}

STIRLING thermal energy conversion in space, heated via a liquid metal cooled reactor is anticipated Sto be an efficient and reliable provider of power on the surface of the Moon and elsewhere. NASA's Exploration Technology Development Program Fission Surface Power Systems Project plans to perform a non-nuclear laboratory demonstration of fission surface power technology using Stirling or Brayton thermal energy conversion. A notional design ${ }^{1}$ is shown in Fig. 1. The technology demonstration will include a liquid metal loop to transport the heat to a power conversion unit for electrical energy production. The waste heat is rejected via heat pipe radiator panels to the walls of a thermal vacuum chamber. Initial demonstration testing will utilize electric heating elements to simulate a nuclear reactor. Prior to conducting a full-scale test, smaller sub-scale testing is planned to demonstrate feasibility. A specific test that is currently being assembled involves the integration of two $1 \mathrm{~kW}$ Stirling convertors from GRC and a NaK heating loop at MSFC. 


\section{A. Fission Surface Power Test Circuit}

The test rig shown in Fig. 2 supplying the heated liquid metal to the Stirling convertors in this initial demonstration can at most heat the NaK to $800 \mathrm{~K}$ at $1 \mathrm{~kg} / \mathrm{sec},{ }^{2,3}$ although an actual reactor could provide more heat than that safely. It also operates in a vacuum chamber at a pressure of $10^{-} 5$ torr or lower. Natural convective cooling is eliminated leaving thermal radiation as the primary energy loss.

The actual reactor temperature and mass flow can be adjusted via fuel rod selection and electromagnetic pumping, but for this demonstration project we assume the coolant has an exit temperature of $798 \mathrm{~K}$. Notice the overall pyramid configuration in Fig. 1 due to the required radiation shielding

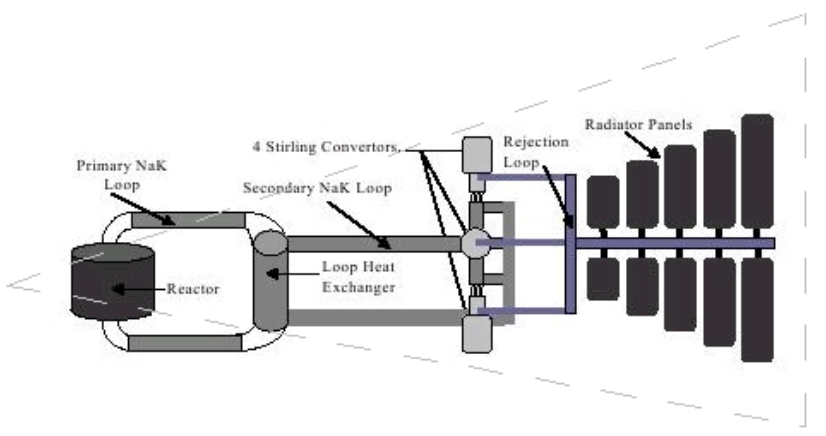

Figure 1. NaK heated Stirling Convertors Notional Layout (Langlois ${ }^{1}$ ) of components. The Stirling linear alternator magnets are located at the outer edge of the pyramid and hence it is imporant to reduce the "footprint" of the dual-opposed Stirling convertors.

Reactors can be cooled with liquids or gases. Water cannot be used with fast spectrum reactors since it acts as a moderator slowing neutrons. Liquid metals have been used in the past for reactor cooling. This demonstration project utilizes $\mathrm{NaK}$ which is an alloy of sodium $(\mathrm{Na})$ and potassium $(\mathrm{K})$ that is commercially available. Alloys with between $40 \%$ and $90 \%$ potassium by weight are liquid at room temperature. The mixture (NaK-78) with the lowest melting point (the eutectic mix), consisting of $78 \%$ potassium and $22 \%$ sodium, is liquid from $260 \mathrm{~K}$ to $1058 \mathrm{~K}$. This allows for convenient frequent shutdown of the reactor since with higher melting point coolants continual heating would be required to prevent freezing of the coolant.

$\mathrm{NaK}$ also has a very low vapor pressure (high boiling point temperature) making it a good choice for the vacuum environment of space. Previous Soviet RORSAT radar satellites were powered by NaK-cooled reactors. Sodium potassium (NaK) was also used in the U.S. SNAP-10A fission reactor.

The test circuit was originally intended to operate with liquid Lithium and has been modified to account for the additional expansion rate of $\mathrm{NaK}$. Since NaK will react with air and water to produce potentially explosive hydrogen reactions, it is important to maintain safe handling prodecures for filling and draining. The entire test is mounted on a tilt table to ensure complete draining. However, the wetted walls will remain wet due to surface tension and a process of "steam cleaning" is envisioned. Gaseous Nitrogen is used to cool the pump to keep the magnetics healthy.

\section{B. Heat Exchanger Design Requirements}

The actual demonstration convertors are manufactured by Sunpower, Inc. notionally shown in Fig. 3 in their dual opposed configuration and a single con-

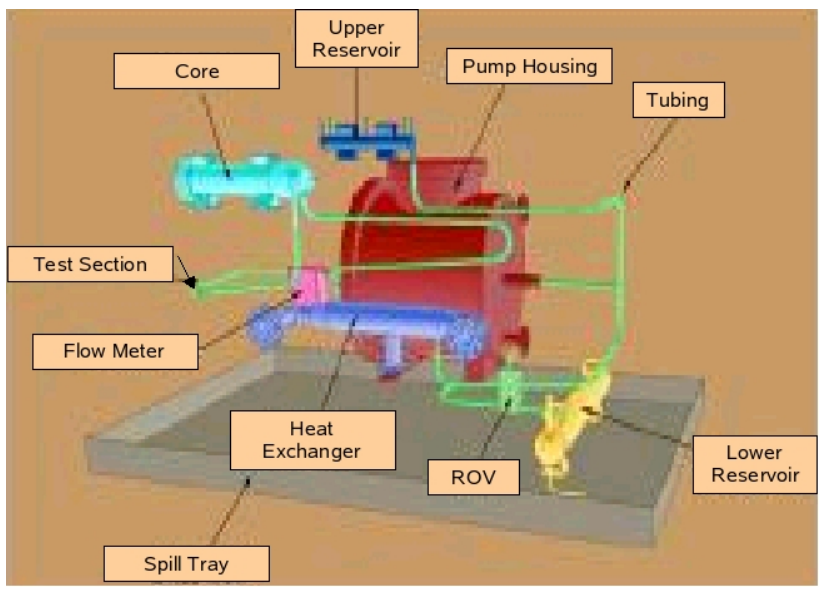

Figure 2. Fission Surface Power Test Circuit (Garber $^{2,3}$ ) vertor with the heat acceptor highlighted.

The ideal P2A liquid metal heat exchanger will have the following properties:

- Provide $4180 \mathrm{~W}$ thermal energy to the convertor

- Minimize mechanical joints

- The liquid metal reactor coolant should drain due to the forces of gravity on the Earth, Moon, and Mars. 


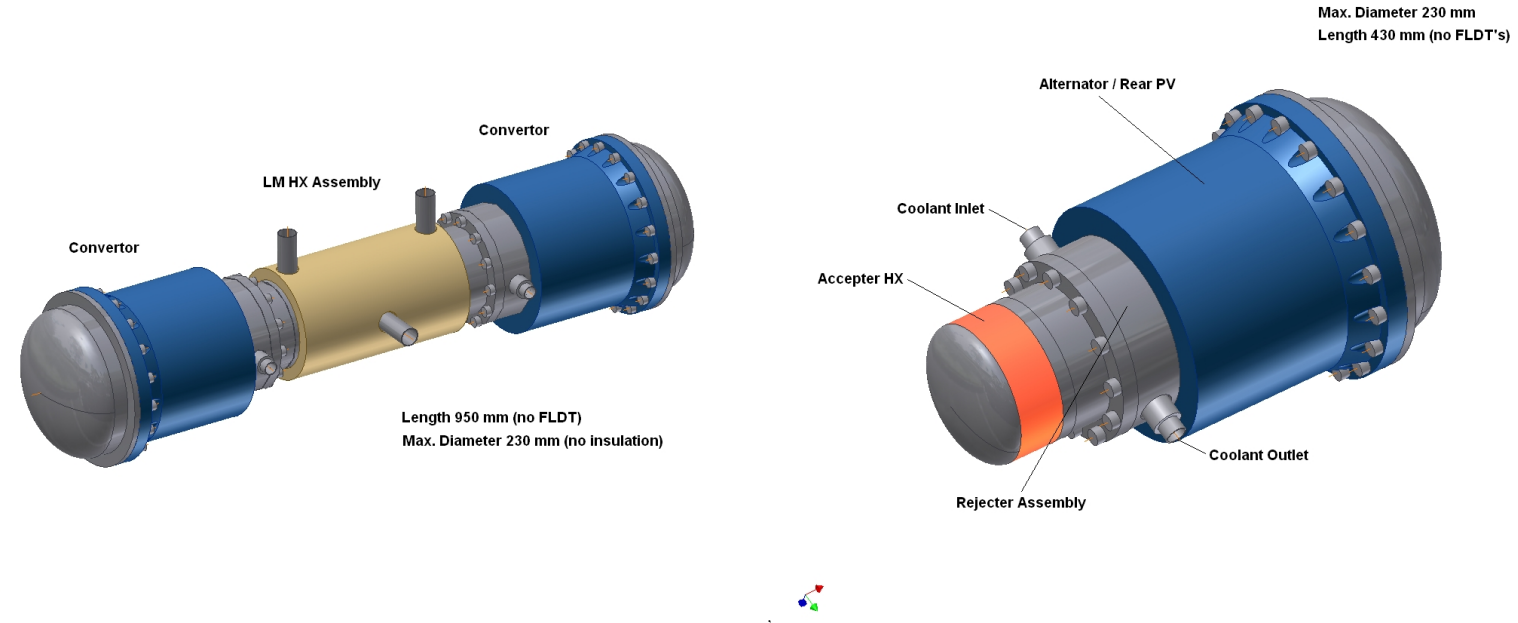

Figure 3. Dual Opposed and Single 1177 W Stirling Convertors (Penswick ${ }^{4,5}$ )

- Maintain a minimum flow velocity to reduce the impact of impurity settling

- Provide a symmetric heat flux to the convertor

- Minimize the temperature difference across the heater head wall (reduce stresses)

- Minimize stresses on the heater head due to differing coefficients of thermal expansion (CTE)

- Minimize pressure drop to reduce the pumping power required

- Account for and mitigate abrasion/erosion both at joints and on the heater head

- Provide long-lived reliable brazes/welds by reducing stresses along these joints/interfaces

- Inexpensive to manufacture

- Reduce the "footprint" of the dual convertors to reduce required radiation shielding for potential future nuclear applications

- Minimize flow direction changes in the supporting plumbing (T's encourage erosion, impact reliability)

This report provides a comparison of various design concepts as they address these criteria by utilizing advanced fluid heat transfer analysis techniques

\section{Heater Head Heat Flux Assumptions}

The accuracy of our model (and effectiveness of our design) is only as good as the assumptions used in the analysis. One of the challenges in this design project is a lack of heat transfer profiles expected at the boundary of the domain. One could model the entire convertor, ${ }^{6}$ to determine the exact heat flux distribution but current time limitations require an engineering estimate of these conditions (i.e. Note that a complete power convertor has many geometric details that effect its peformance and heating requirements)

A number of previous studies have assumed either a constant temperature along the acceptor or a constant heat flux. For example, a previous analysis for a thermal vacuum test rig assumed a $15 \mathrm{~K}$ temperature drop along the length of the acceptor and a constant heat flux. ${ }^{7}$ In Fig. 4(a) heat conduction from an electric source is used to heat the acceptor. In Fig. 4(b), a uniform flux is assumed a distance away from the wall to minimize the effect of boundary condition errors.

Also, Sage ${ }^{8}$ analysis (a globally implicit harmonic one-dimensional Navier-Stokes solver and Stirling engine optimizing software package) assumes a temperature difference along the acceptor. And the expansion 
as a cooler (i.e. piston leads the displacer).



(a) Electric Heating Configuration

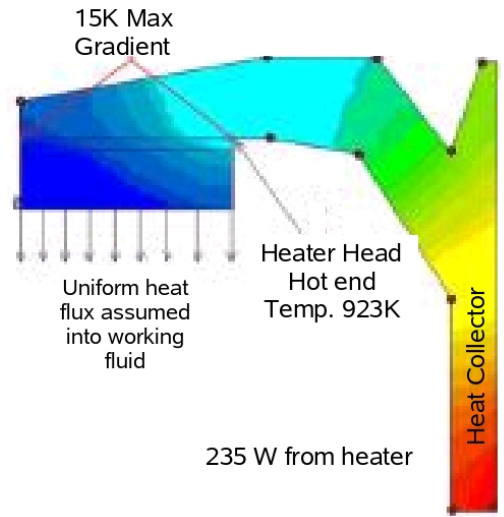

(b) Wall Temperature Distribution

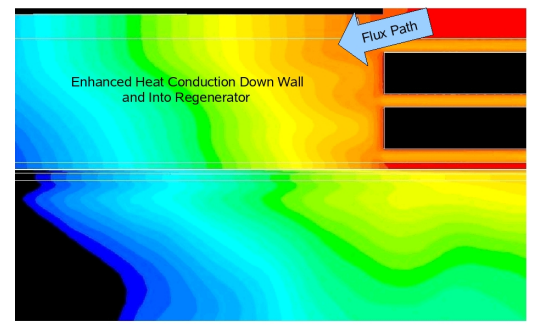

(c) Heat Flux into Regenerator

Figure 4. Delta Temperaure Along Acceptor (Oriti ${ }^{7}$ )

space is often treated with only a few cells, each with a single temperature resulting in an approximate heat flux profile.

In Fig. 5(a) is shown the heat flux profile predicted from a Sage/FEA analysis. Again, the temperature distribution is assumed at the wall, not the heat flux, resulting in a large heat flux at the dome end of the acceptor to maintain the high temperature. Notice in the graph that when a $20 \mathrm{~K}$ temperature drop is assumed this results in a lower heat flux at the dome end. Since the delta $\mathrm{T}$ is being provided as an input, the resulting heat flux profile is again only an approximation. The slight increase in the heat flux profile near the regenerator can be observed in Fig 4(c) to be due to the increased conduction along the wall and radial conduction into the regenerator.

In recent whole engine simulations, a constant temperature was assumed on the heat exchanger and the resulting oscillating heat flux is shown in Fig. 5(b). Typically a time average of this profile is assumed for the purposes of designing the heat supply interface to the acceptor.

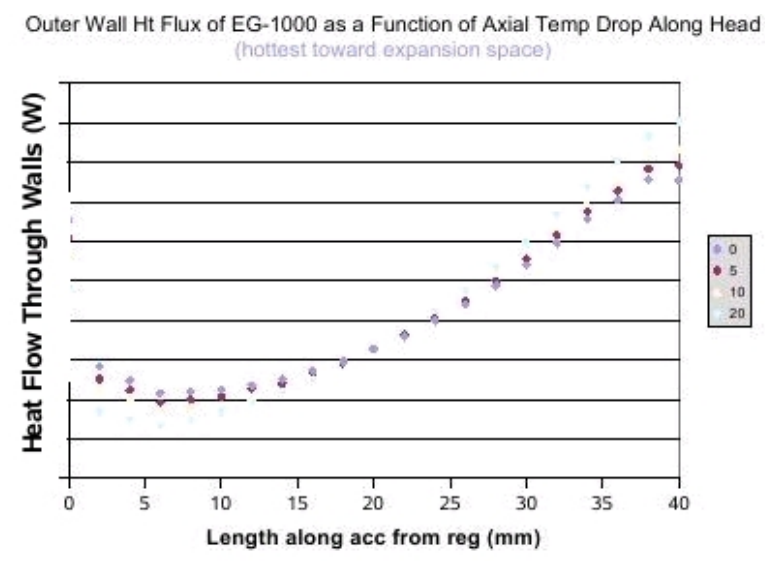

(a) Wall Heat Flux $\left(\right.$ Wood $\left.^{9}\right)$

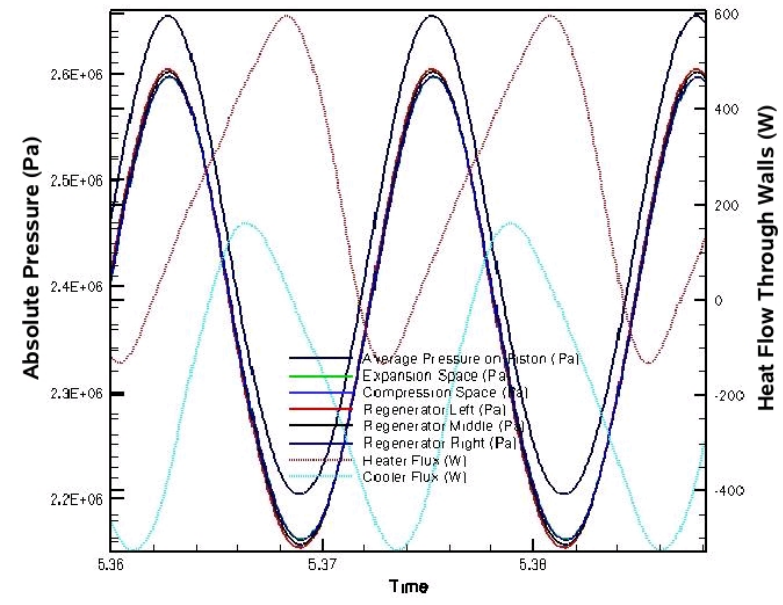

(b) Wall Heat Flux Oscillation $\left(\right.$ Dyson $^{10}$ )

Figure 5. Heater Head Wall Flux

Also, under the assumption of fixed wall temperature, notice the temperature profile through the entire engine in Fig. 6. Notice the dome temperature becomes essentially uniform. In our current analysis of the liquid metal heat exchanger, we assume a fixed temperature along the dome as well. If we assume only $10 \%$ heat transfer in through the dome, the effective dome temperature must be higher than the acceptor temperature because the liquid metal cools upon impinging the dome (in the case of axially entering flow). Notice that the dome wall becomes much cooler than the acceptor when the convertor is operating in reverse 
as a cooler (i.e. piston leads the displacer).

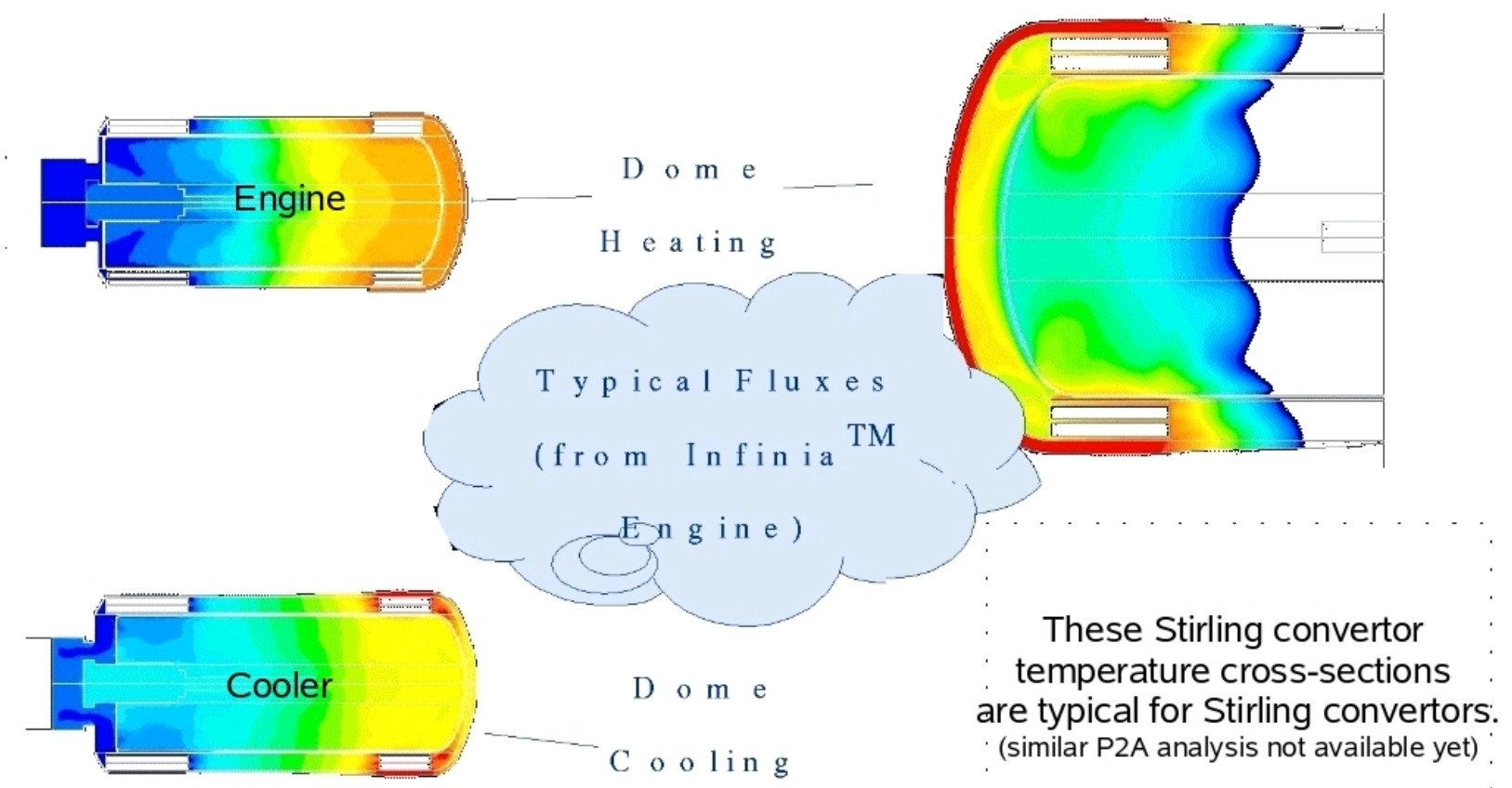

(a) Heater and Cooler Profiles Shown

Figure 6. Typical Fluxes Through the Heater Head

Experimental evidence ${ }^{11}$ indicates that the heater head dome is actually slightly cooler than the acceptor region when the heat is delivered directly to the acceptor. Once we apply liquid metal to the dome this condition may no longer be true, but more heat transfer overall is possible into the Stirling heater head in this circumstance due to effectively more heat transfer surface area.

These previous studies indicate a variety of approximations which are often applied to estimate the effective heat flux and serve to bracket the variability expected in our analysis. In Fig. 7, the effects of assuming either a constant heat flux or a constant temperature along the acceptor are shown including the liquid metal temperature profile and heat flux axially along the acceptor. For example, if the NaK is flowing at a rate of $.17 \mathrm{~kg} / \mathrm{s}$ and the heat flux profile is assumed to be constant, then the temperature profile shown in Fig. 7(a) of the liquid metal gradually cools along the length. In contrast, when the temperature is assumed constant, then the liquid metal must quickly cool near the surface as shown in 7(b) resulting in a spiking higher heat flux at the entrance. For our final heat exchanger design both assumptions were made to bracket the predicted performance.

\section{A. Correlations}

Traditionally, engineers have relied on empirical correlations of heat transfer coefficients (HTC) to estimate convection heating (fluid to solid). Those correlations are valid only in a particular flow regime and only under developed flow conditions. Interestingly, the correlations themselves are based on a non-dimensionalization of the Navier-Stokes equations (Buckingham-PI rule) and then experiments are performed to attempt to fit a curve to the data.

For example, the heat lost from a hot tube to the surrounding area:

$$
Q=h \cdot A \cdot \Delta T
$$

The unknown is always the heat transfer coefficient, $h$, until experiments can be performed, and then only for specific fluids, flow regimes, and thermodynamic conditions. The Dittus-Boelter heat transfer relation ${ }^{12}$ 


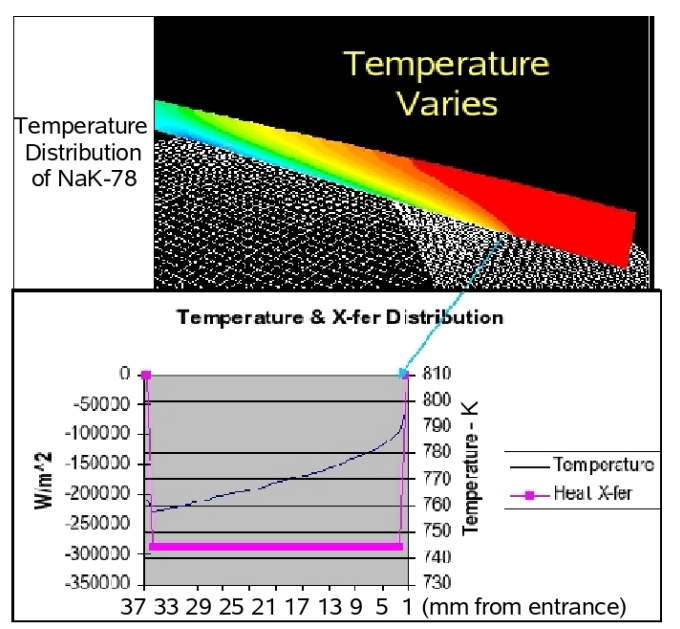

(a) Heater Head-Constant Heat Flux, Varying Temperature Mass Flow .17 $\frac{\mathrm{kg}}{\mathrm{s}}$, Heat Transfer 4165W, $\Delta \mathbf{P}$ 7.6 Pa

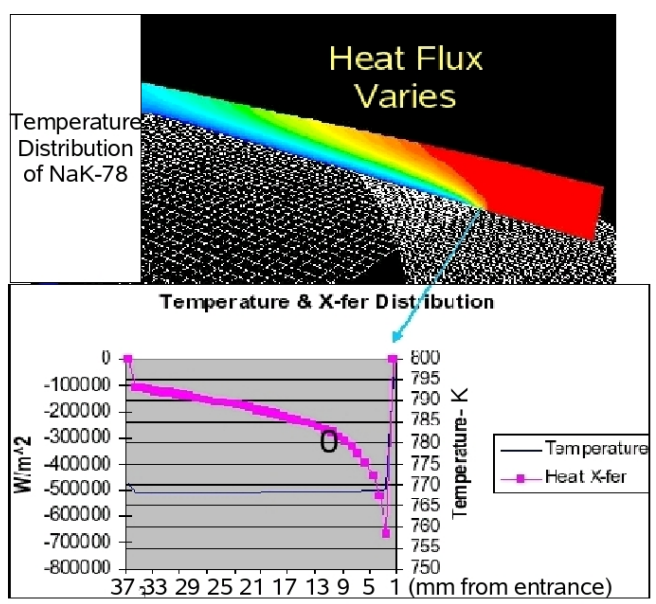

(b) Heater Head-Constant Wall Temperature, Varying Flux Mass Flow .17 $\frac{\mathrm{kg}}{\mathrm{s}}$, Heat Transfer 3676W, $\Delta \mathbf{P}$ 7.6 Pa

Figure 7. Effects of Heat Exchanger Heat Transfer Assumptions

is valid for a wide range of fluids, including water, in a circular pipe with Reynolds numbers between 10,000 and 120,000 and Prandtl numbers in the range between 0.7 and 120. The heat transfer coefficient (HTC) is:

$$
\begin{gathered}
h=\frac{k_{w} \cdot N u}{D_{h}} \\
N u=0.024 \cdot R e^{0.8} \cdot \operatorname{Pr}^{0.4}
\end{gathered}
$$

\section{B. Annular Heat Exchanger Correlation}

For the case of an annular heat exchanger, with inner Diameter, $D_{i}$, and outer diameter, $D_{o}$, with an insulated outer wall and constant temperature inner wall, the heat flux transfer from the wall is:

$$
q_{i}=h_{i}\left(T_{i}-T_{\text {fluid }}\right)
$$

and the Nusselt number:

$$
N u_{i}=\frac{h_{i} D_{h}}{k}
$$

where $D_{h}=D_{o}-D_{i}$.

The heat transfer coefficient for fully developed laminar flow may be found by the Table 1. Clearly, the heat transfer cofficient increases as the outer diameter decreases. This implies the flow volume should decrease in the direction of the flow if it is desired to increase the heat transfer coefficient to maintain a uniform heat flux since the NaK's temperature is decreasing along the acceptor as it releases heat.

Other heat transfer coefficients for liquid metal may be found in Weisman. ${ }^{13}$ The limitation of the heat transfer coefficients is they typically apply only in very specialized flow regimes and entrance effects are typically not accounted for. Fortunately,

\begin{tabular}{cc}
\hline \hline$D_{i} / D_{o}$ & $N u_{i}$ \\
\hline 0 & $\mathrm{NA}$ \\
0.05 & 17.46 \\
0.10 & 11.56 \\
0.25 & 7.37 \\
0.50 & 5.74 \\
1.00 & 4.86 \\
\hline \hline
\end{tabular}

Table 1. Laminar Developed

Flow Annular Duct Heating by solving the Navier-Stokes equations directly we don't need the empirical heat transfer correlations since 
we are effectively performing the experiment that the correlations would have been derived from while simultaneously including the entrance and exit effects.

For the case of constant or variable heat flux, more complicated influence coefficients are employed, further exacerbating the difficulty of validating the results. A fully computational fluid dynamic analysis is employed instead, and its formulation is detailed next.

\section{Numerical Approach}

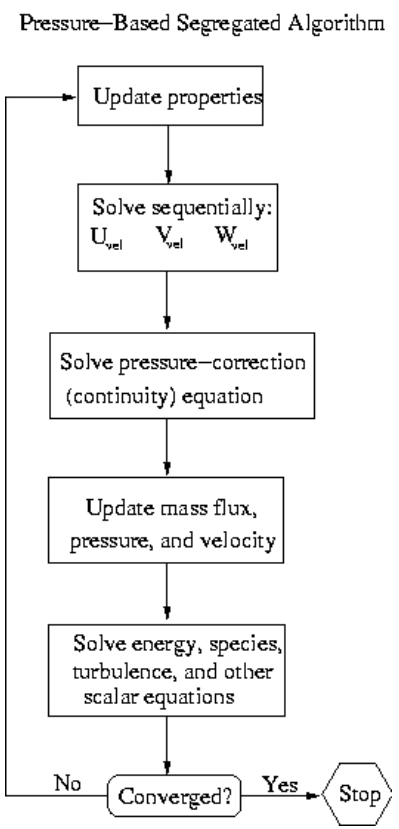

(a) Segregated Solver

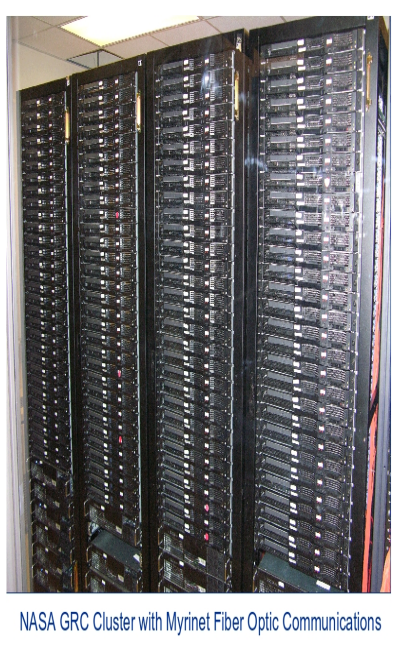

(b) Computer Cluster
Figure 8. Solver Tools

There are a number of computational fluid dynamics tools available for accomplishing this work including Modified CAST, CFD-ACE, Fluent, STAR-HPC, CFX/ANSYS, and many others that are all low order accuracy solver based. Some new high-order codes are being developed that are less stable, but provide faster solution times. The low order methods seem to be able to use about 30 processors efficiently. So it is important to run many cases at once to fully utilize a large computer cluster. In this work, many design optimizations were tested simultaneously.

\section{A. Solver}

A pressure based solver is used where the NavierStokes equations are solved sequentially (segregated from one another) as outlined in Fig. 8(a). The pressure derivatives are discretized using a bodyweighted formulation. The face pressure is determined by assuming that the normal gradient of the differences between pressure and body forces is constant. This is used due to the large body forces occuring in the high density liquid metal (especially when compared to water or Helium) The gravity forces are added as a source term as well for this reason. It is assumed the liquid metal is flowing in the laminar regime. The thermodynamic fluid properties assumed are shown in the Appendix Fig. 16.

Some of the designs examined contained unsteady flow features such as vortices, mixing, and reversed flow. It was necessary to solve the unsteady Navier-Stokes equations in those cases. Also, since the heat flux at the acceptor actually oscillates during the cycle (see Fig. 5(b)), a more exact analysis would require accounting for unsteady heat flux effects in an complete unsteady analysis. And, such effects as the reactor startup impulse are currently ignored but would require an unsteady analysis as well.

The current heat exchanger analysis was carried out on a 374 processor cluster as shown in Fig. 8(b). The solution process involves:

- Meshing Technique

- avoiding tetrahedral cells during meshing,

- matching cell sizes across non-conformal regions,

- smoothly expand/shrink cells through domain,

- utilizing double-sided boundary layers,

- Geometry Technique

- including as much geometry as is practical,

- cleaning up the geometry in CAD rather than using virtual geometry, Solver Technique 
- over-converge the steady solution to improve grid (by identifying local instability regions),

- maximize the energy under-relaxation factor,

- disable secondary temperature gradients,

- emphasize the course multigrid to avoid round-off error,

- utilize explicit under-relaxation of temperature,

- utilize higher space and time accuracy whenever possible,

- Optimization

- utilize parallel processing to perform design optimization.

- bound the results with both constant heat flux or temperature assumptions

- apply about 30 processors per design, but solve many parametric cases at a time

\section{Design Evolution}

This effort is the first time that a Stirling engine will be directly heated with single-phase liquid metal NaK-78 and careful attention was given to accounting for the very high thermal conductivity and viscous, body force dominated convective motions. A number of conceptual designs were analyzed computationally as shown in Fig. 9. The designs are first characterized by either a predominantly axial or radial motion of the liquid metal past the acceptor surface. Secondarily, the angle at which the flow enters or exits the heat exchanger further delineates the categories.

Each of the following design concepts will be described fully in subsequent sections:

- The axially slanting entrance and exit case was first examined (Fig. 9(a)) with the arrows indicating direction of flow and the overall flow pattern being both radial and axial (diagonally across the acceptor).

- The second concept (Fig. 9(b)) resulted in purely radial flow but minimized erosion on the heater head.

- The third concept (Fig. 9(c)) produced very symmetrical axial flow at the entrance, but somewhat eratic heat fluxes due to excessive back pressures.

- The fourth concept (Fig. 9(d)) produced purely radial flow with a surprisingly symmetric heat flux.

- The fifth concept (Fig. 9(e)) resulted in very uneven heat fluxes due to vortical flow structures.

All of these concepts eventually lead to our final design that is very similar to Fig. 9(c)), but that is presented later in section VI.

\section{A. Angled Entrance, Angled Exit}

The first conceptual design considered and its predicted performance is shown in Fig. 10. The liquid metal is assumed to enter the tube at $798 \mathrm{~K}$ and the walls are assumbed to be perfectly insulated (adiabatic). The first column in the figure represents the originally desired performance of the heat exchanger across the Stirling acceptor. The heat flux was assumed to be constant, thus allowing the temperature to vary. Notice the mass flow rate in was reduced by $30 \%$ under this heat flux assumption. A constant temperature assumption requires the higher flow rate.

The overall heat flux was at the correct level, but the heat flux profile was very unsymmetrical and would have potentially caused performance degradation of the Stirling convertors due to non-symmetrical thermal energy input through the heat acceptor. Also, the overall temperature drop across the acceptor was 50K which is large compared to previous analysis and experimental results. 


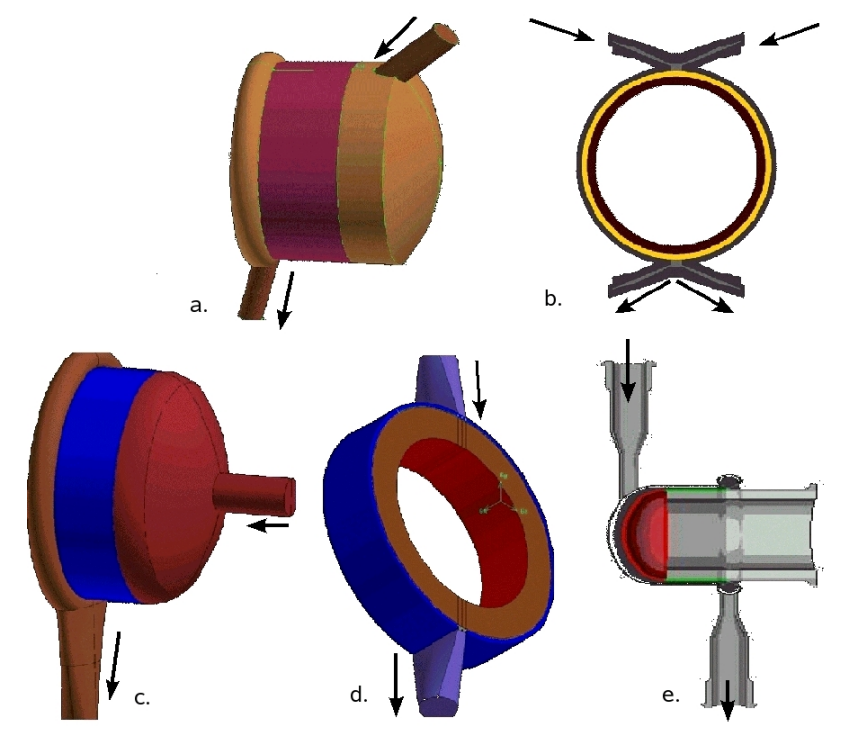

Figure 9. Preliminary Cases Considered a). Angled Entrance, Angled Exit b). Radial Flow with Split Entrance/Exit c). Symmetric Entrance, Toroidal Back-End, Conical Drain, d). Radial Flow with Single Entrance/Exit, e). Radial to Axial

\begin{tabular}{|l} 
|l|l|l| \begin{tabular}{|l|l|l|}
\hline Wall Temp. & $768.15 \mathrm{~K}$ & $742-797 \mathrm{~K}$ \\
\hline LM Inlet & $798.15 \mathrm{~K}$ & $798.15 \mathrm{~K}$ \\
\hline LM Temp. Drop & $20 \mathrm{~K}$ & $25 \mathrm{~K}$ \\
\hline Thermal to Conv. & $4180 \mathrm{~W}$ & $4165.5 \mathrm{~W}$ \\
\hline LM Flow Rate & $.24 \mathrm{~kg} / \mathrm{s}$ & $.17 \mathrm{~kg} / \mathrm{s}$ \\
\hline LM Volum. rate & $3.18 \mathrm{e}-4 \mathrm{~m}^{\wedge} 3 / \mathrm{s}$ & $2.268 \mathrm{e}-4 \mathrm{~m}^{\wedge} 3 / \mathrm{s}$ \\
\hline Avg. HX heat flux & $28.7 \mathrm{~W} / \mathrm{cm}^{\wedge} 2$ & $28.69 \mathrm{~W} / \mathrm{cm}^{\wedge} 2$ \\
\hline Entrance Height & $4.5 \mathrm{~mm}$ & $4.5 \mathrm{~mm}$ \\
\hline Exit Height & $3.45 \mathrm{~mm}$ & $3.45 \mathrm{~mm}$ \\
\hline LM Pressure Drop & $55 \mathrm{~Pa}$ & $552 \mathrm{~Pa}$ \\
\hline
\end{tabular}
\end{tabular}

Figure 10. Flooded Dome, Angled Inlet/Outlet, Nominal VS. Achieved Performance

\section{B. Radial Flow with Split Entrance/Exit}

Results for the radial flow concepts (Figs. 9(b) are shown in Fig. 11 and in this case consists of two inlet channels that enters radially from the top of the heater head. The two inlets force the metal to collide, thereby reducing the impact force on the heater head. A copper spreader is used to more evenly distribute the heat circumferentially. A thin insulating shield is shown in Fig. 11 and it serves to protect the copper from erosion and with proper thickness "tuning" the heat flux and temperature can be made radially symmetric about the acceptor. The exit consists of two radially extended outlet tubes.

Since the effects of radially/circumferentially uneven heating (though axially uniform) of the Stirling convertor are not presently characterized, a more conservative axially varying, circumferentially uniform heat flux profile is desired.

\section{Symmetric Entrance, Toroidal Back-End, Conic Drain}

The third design under consideration is one in which the flow directly impinges the dome axially and then evenly spreads around the dome and over the heat exchangers. With a NaK-78 mass flow of $.24 \mathrm{~kg} / \mathrm{s}$ and assumed inlet temperature of $798 \mathrm{~K}$, the expected outlet average temperature is $779 \mathrm{~K}$ with a total energy delivery of $3885 \mathrm{~W}$.

These results are shown in Figs. 12. Note that the temperature along the acceptor wall is assumed 


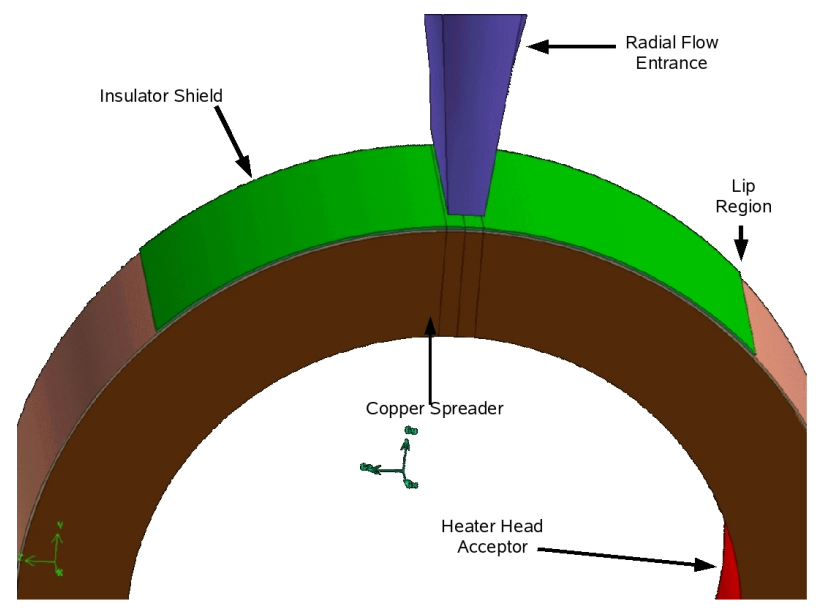

(a) Side

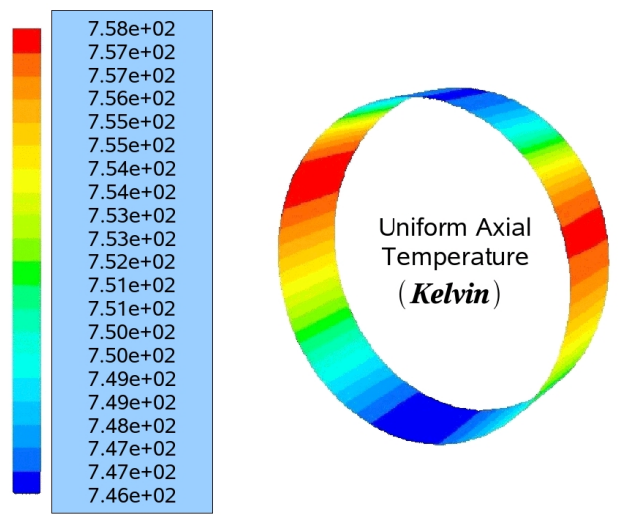

(c) Temperature Acceptor

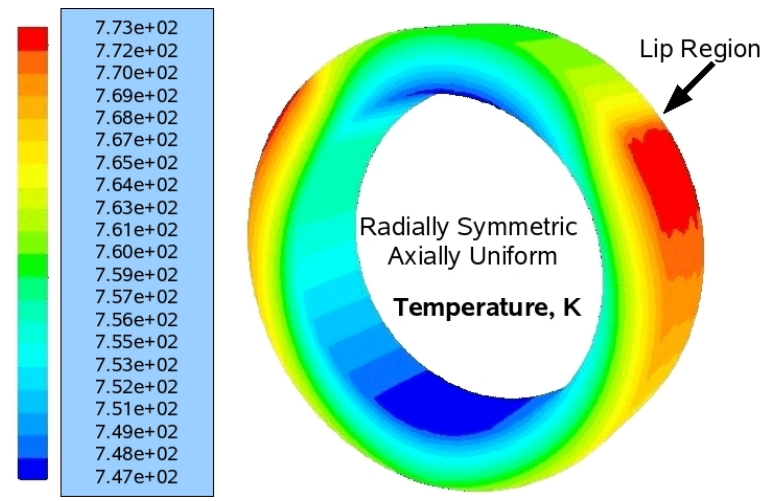

(b) Symmetric Temperature Distribution


(d) Heat Flux Constant Temperature

Figure 11. Radial Concentric

constant at $768 \mathrm{~K}$. But as shown in Fig. 12(d), the heat flux is not symmetrical around the acceptor. This is partly explained by the unsymmetrical pressures shown in Fig. 12(e) in which a back pressure is forcing a reversed flow on the top half of the heat exchanger. If the dome is not considered adiabatic and some of the liquid metal heat energy conducts into the expansion space then the total energy delivered is a little higher at $4070 \mathrm{~W}$.

Since the heat flux is not symmetrical about the acceptor, this design was considered inadequate; however the final design is most similar to this one.

\section{Radial Flow with Single Entrance/Exit}

This concept is a refinement of the Split Entrance/Exit concept shown in Fig. 9 (b). Rather than attempt to minimize the impact of the liquid metal on the heater head through split entrance collision, an insulating shield is used to both protect the head from impact and spread the heat flux appropriately. This concept appears promising but it is not clear how the Stirling engine would respond to this axially symmetric, circumferentially varying heat flux.

\section{E. Radial to Axial}

The radial to axial concept in Fig. 9(e) appeared promising since it shared many of the features with the Symmetric Entrance, Toroidal Back-End, Conical Drain case (Fig. 9(c)) and it appeared to provide good drainage of the liquid metal. Unfortunately, the required tight angle at the entrance forced most of the flow downward upon impact resulting in very uneven heating. 


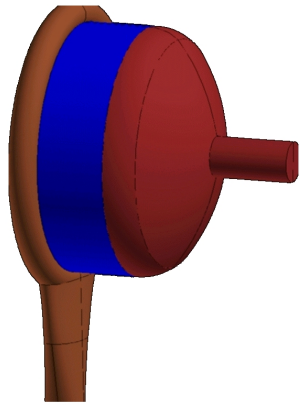

(a) Side View

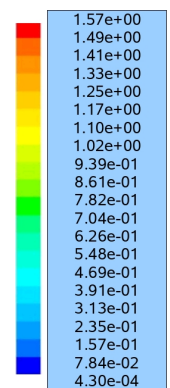

(b) Velocity

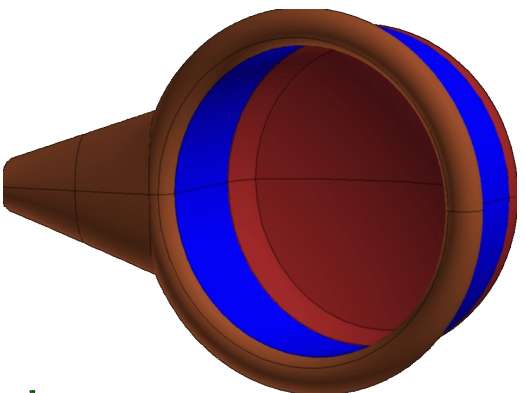

(c) Bottom View - Acceptor colored blue
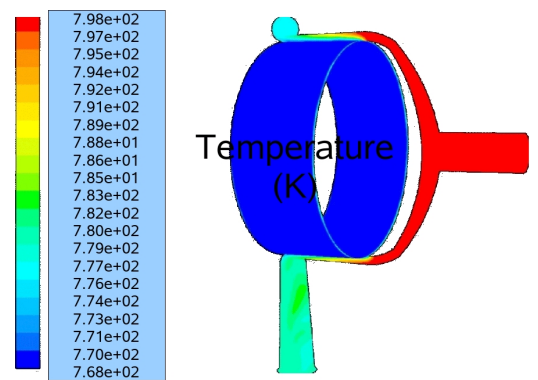

(f) Temperature

(d) Heat Flux

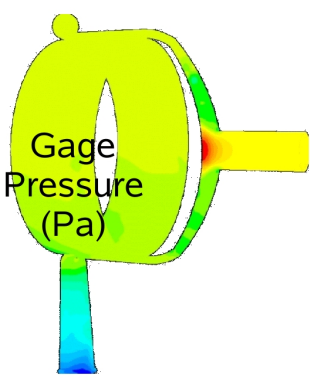

(e) Pressure

Figure 12. Axially Flooded Entrance, Toroidal Exit - Constant Temperature Along Acceptor

\section{Initial Reference Concept \& Summary}

A preliminary concept design is shown in Fig. 13(a) and was the first to include a full stress analysis and ease of manufacturing in its design. Unfortunately, the liquid metal analysis indicated this was actually the worst performing due to extremely uneven heating. Some areas around the top of the acceptor did not receive any liquid metal heating!

A summary of the predicted performance of the candidate designs is shown in Fig. 13(b). Interestingly, a good candidate design is the radial heat exchanger (Fig. 9(d)); however, a final axial design is presented next that matches this performance and provides a more conservative axial flow across the acceptor.

\section{Final Configuration \& Fabrication}

The final design is shown in Fig. 14. Notice the similarity with the third case shown in Fig. 9(c). The primary difference is the larger torus (now shaped elliptically for stress management) and the inner curved lip that prevents the NaK from backflowing into the acceptor region.

A comparison of the original design goal with the final design's performance is shown in Table 2. The total pressure drop is about $820 \mathrm{~Pa}$, the maximum flow velocity is $1.874 \mathrm{~m} / \mathrm{s}$, the NaK-78 mass flow rate is: $.24 \mathrm{~kg} / \mathrm{s}$, the total heat accepted into the Stirling convertor is: $4659 \mathrm{~W}$, and the enthalpy flux into the inlet of the heat exchanger is: $107,888 \mathrm{~W}$.

Notice the entrance and exit heights correspond to the radial gap along the acceptor. Originally it was anticipated that as the temperature of the liquid metal dropped along the length of the acceptor that the heat transfer coefficient would need to be gradually increased to maintain a constant temperature along the acceptor. Since this would have resulted in difficulties with gravity draining the NaK-78 the same entrance and exit height was used instead with little impact upon the performance of the heat exchange system.

A picture of the as fabricated heat exchanger and the very uniform heat flux is shown in Fig. 15. All performance goals are achieved with this design. 


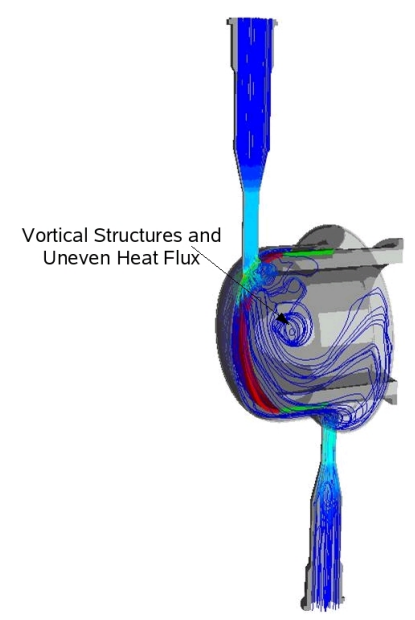

(a) Preliminary Design

\begin{tabular}{|c|c|c|c|}
\hline Candidate & $Q_{\text {in }}(W)$ & $\Delta T_{\text {acceptor }}(\mathrm{K})$ & $\Delta T_{\text {pressure }}(\mathrm{Pa})$ \\
\hline & 4165.5 & 55 & 552 \\
\hline & & & \\
\hline & 4180 & 11 & 450 \\
\hline & 4251 & 20 & 2100 \\
\hline & & & \\
\hline
\end{tabular}

(b) Summary of Preliminary Designs

Figure 13. Preliminary Design Summary

\begin{tabular}{ccc}
\hline \hline Property & Design Goal & Achieved Performance \\
\hline Wall Temperature & $768 \mathrm{~K}$ & $768 \mathrm{~K}$ \\
LM Inlet Temp. & $798 \mathrm{~K}$ & $798 \mathrm{~K}$ \\
LM Temp. Drop & $20 \mathrm{~K}$ & $22 \mathrm{~K}$ \\
Thermal to Conv. & $4180 \mathrm{~W}$ & $4659 \mathrm{~W}$ \\
LM Flow Rate & $.24 \mathrm{~kg} / \mathrm{s}$ & $.24 \mathrm{~kg} / \mathrm{s}$ \\
LM Volume Rate & $3.18 \mathrm{e}-4 \mathrm{~m}^{3} / \mathrm{s}$ & $3.18 \mathrm{e}-4 \mathrm{~m}^{3} / \mathrm{s}$ \\
Avg. HX Heat Flux & $28.7 \mathrm{~W} / \mathrm{cm}^{2}$ & $31.8 \mathrm{~W} / \mathrm{cm}^{2}$ \\
Entrance Height & $4.5 \mathrm{~mm}$ & $3.45 \mathrm{~mm}$ \\
Exit Height & $3.45 \mathrm{~mm}$ & $3.45 \mathrm{~mm}$ \\
LM Pressure Drop & $55 \mathrm{~Pa}$ & $820 \mathrm{~Pa}$ \\
\hline \hline
\end{tabular}

Table 2. Final Design, Nominal VS. Achieved Performance 


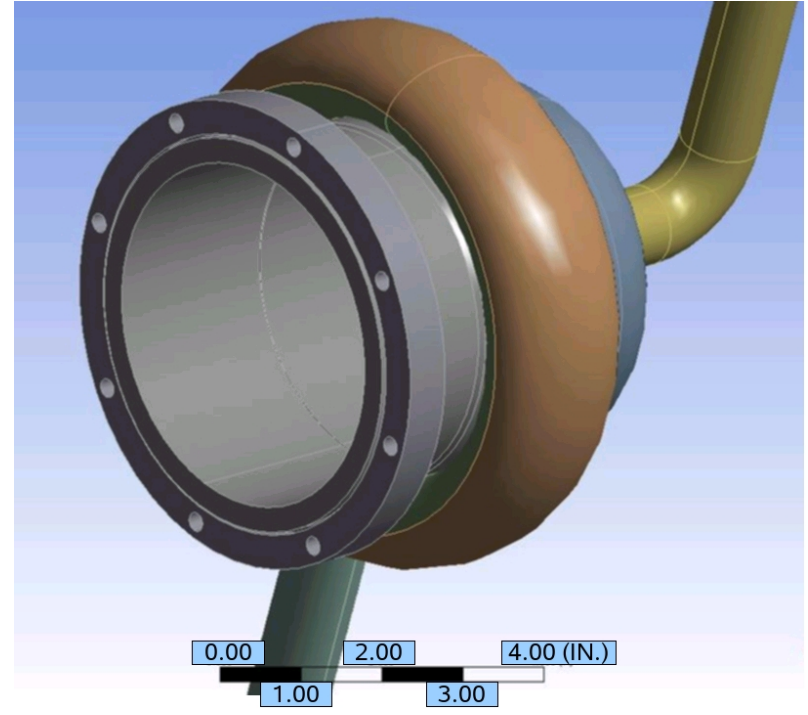

(a) Final Design Layout

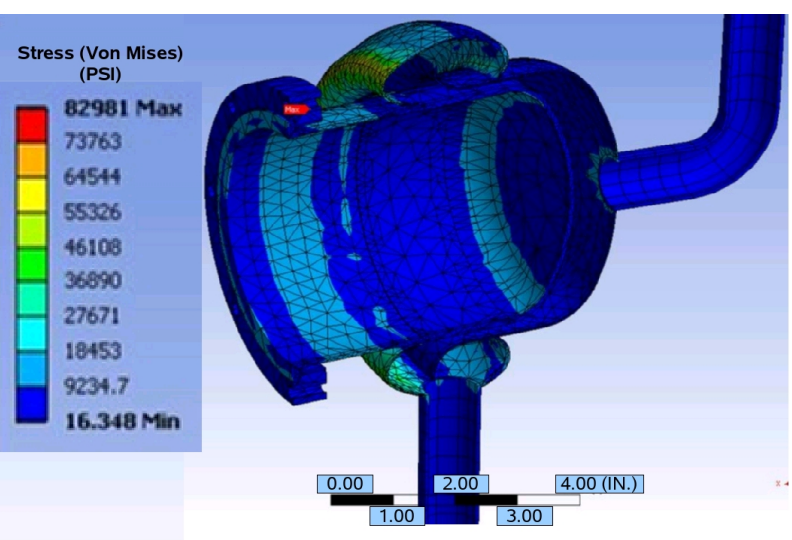

(c) Stress

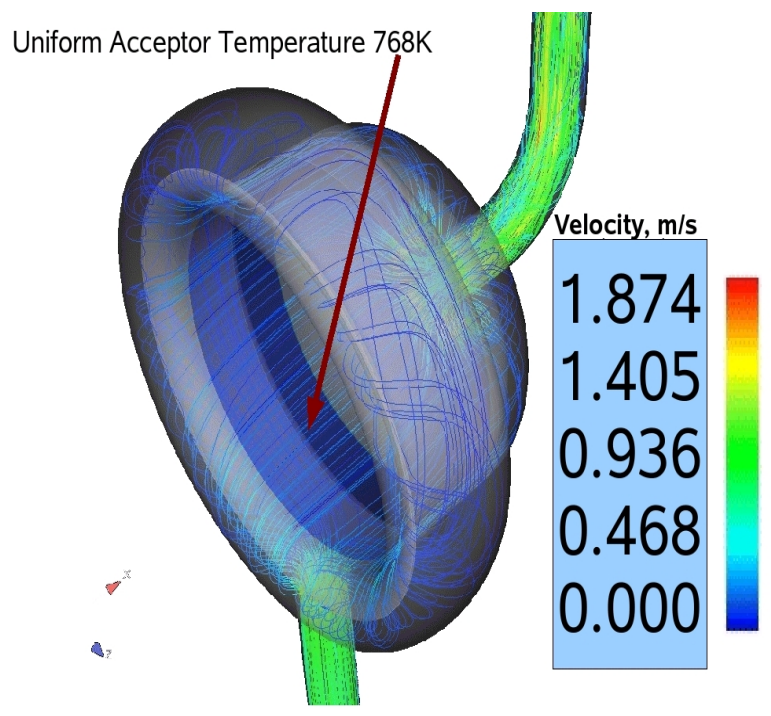

(e) Velocity

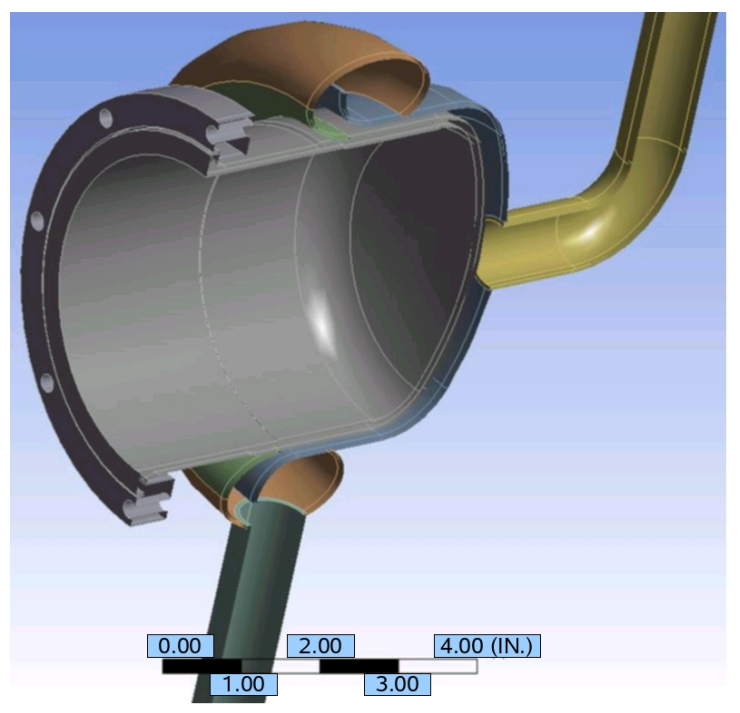

(b) Cut-Away View



(d) Deformation

Impact Pressure Rise

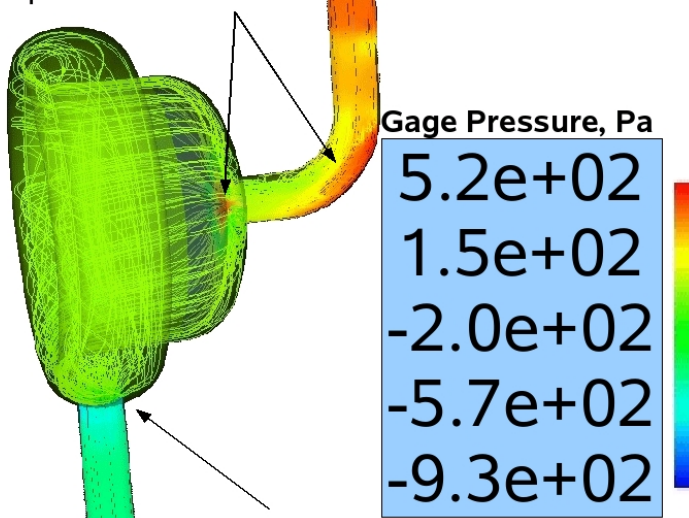

Localized Pressure Drop

(f) Pressure

Figure 14. Final Liquid Metal Heat Exchanger Design: Stress, Deformation, Velocity, and Pressure 

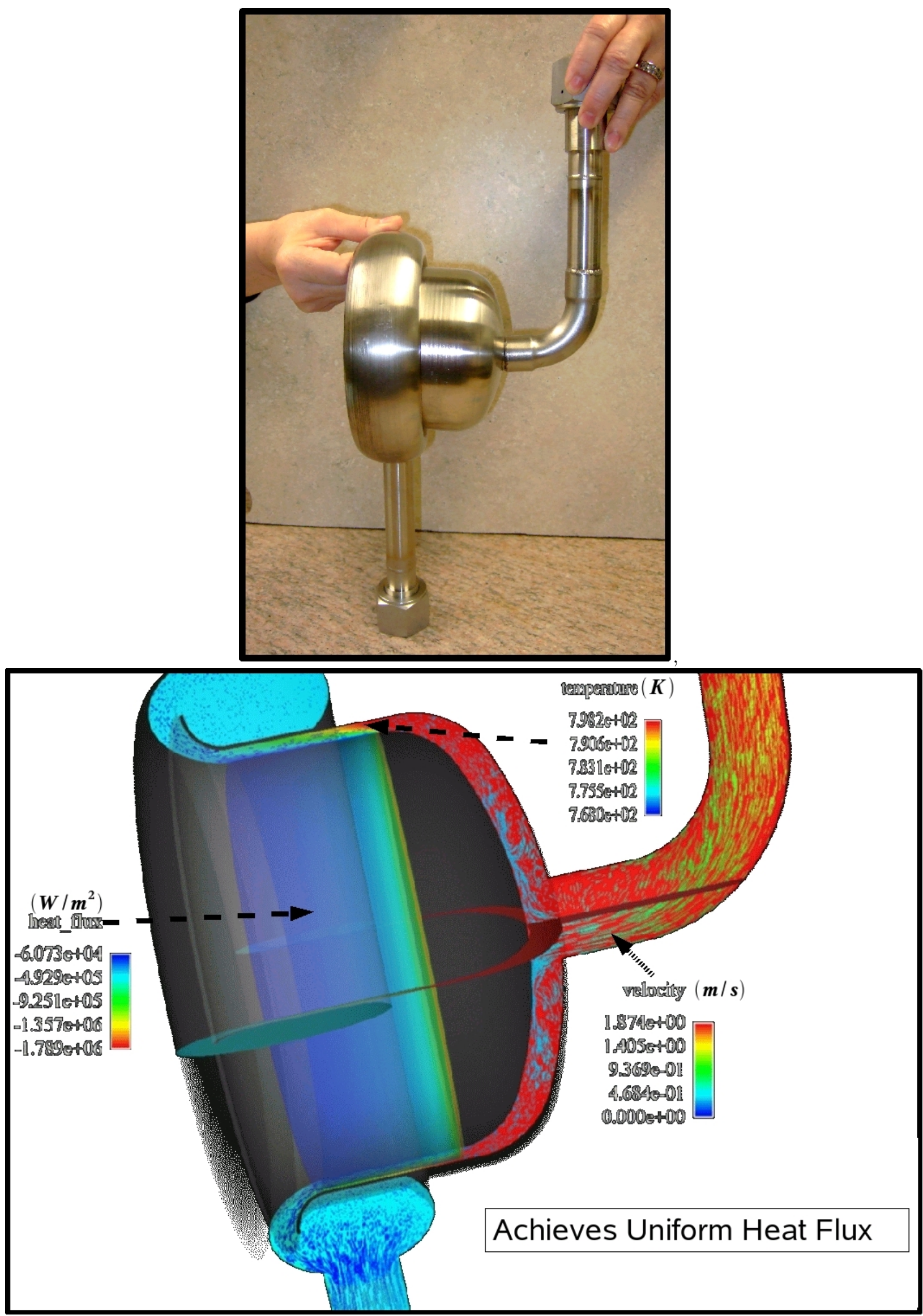

Figure 15. Final Design as Fabricated 


\section{Conclusion}

The final heat exchanger design is being fabricated from stainless steel and will be tested at NASA Marshall's Fission Test Power Circuit facility. It utilizes a flooded axial entrance to achieve uniform flow around the heater head acceptor. It provides some heating through the dome and the balance enters through the acceptor with the NaK temperature dropping about $22 \mathrm{~K}$ along the acceptor length. After several design iterations, it was found that an elliptical torous with an inner curved lip reduced uneven back pressures to achieve an essentially perfect heat flux distribution across the acceptor.

Despite the variability in the heat flux profile assumed, the reactor coolant mass flow can be adjusted to compensate for any minor inaccuracies to ultimately deliver acceptable heat energy to the convertor. At most, the mass flow rate would need to be adjusted up or down approximately $30 \%$ from the mean of .24 $\mathrm{kg} / \mathrm{s}$ to achieve this.

\section{A. APPENDIX: Sodium Potassium Thermodynamic Properties}

The density, specific heat, conductivity, and viscosity for the eutectic mixture of liquid Sodium Potassium is shown in Fig. 16. Notice that for the temperature range the heat exchanger operates in the properties are essentially constant. However, the fully variable property characteristics were included in the computational fluid dynamic analysis of the exchanger system.

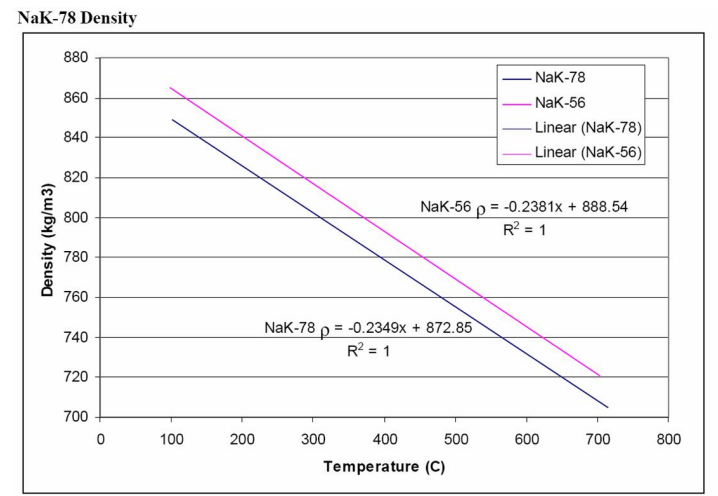

Reference: Burdi, G. F., "SNAP TECHNOLOGY HANDBOOK" Volume 1, Liquid Metals, Atomic International Report No. NAA-SR-8617 (August, 1964).

(a)

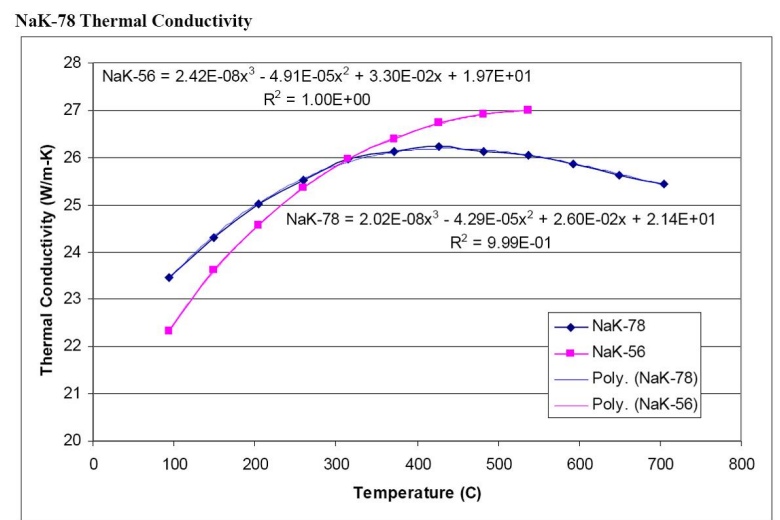

Reference: Burdi, G. F., "SNAP TECHNOLOGY HANDBOOK" Volume 1, Liquid Metals, Atomic International Report No. NAA-SR-8617 (August, 1964).

(c)

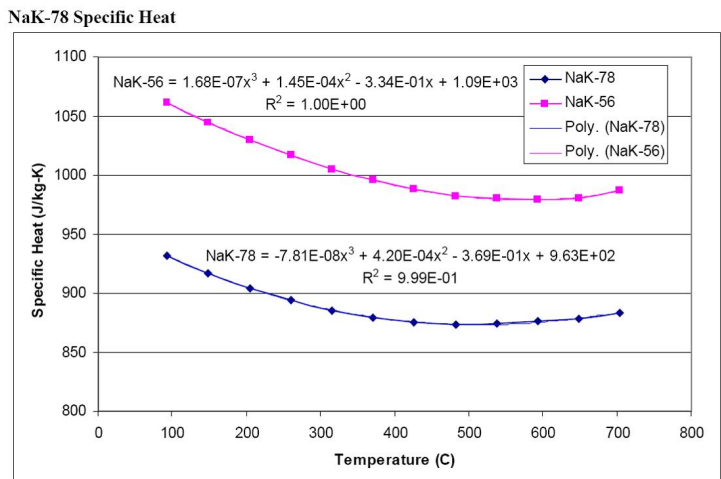

Reference: Burdi, G. F., "SNAP TECHNOLOGY HANDBOOK" Volume 1, Liquid Metals, Atomic International Report No. NAA-SR-8617 (August, 1964).

(b)

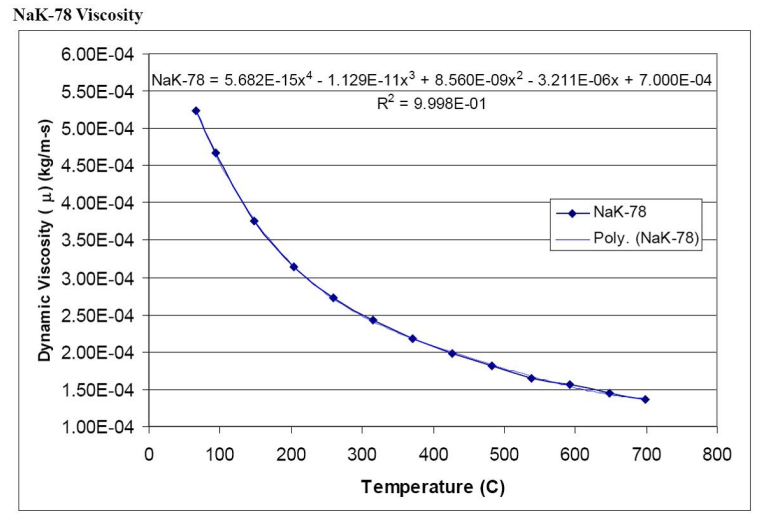

Reference: Burdi, G. F., "SNAP TECHNOLOGY HANDBOOK" Volume 1, Liquid Metals, Atomic International Report No. NAA-SR-8617 (August, 1964).

(d)

Figure 16. NaK-78 Properties 


\section{References}

${ }^{1}$ Langlois, J.L.R., Myre, D., Nelson, M. "Dynamic Computer Model of a Stirling Space Nuclear Power System", 5th Internation Energy Conversion Engineering Conference (IECEC), 25027 June 2007, St. Louis, Missouri, AIAA-2007-4774

${ }^{2}$ Garber, A.E. "Capabilities and Testing of the Fission Surface Power Primary Test Circuit (FSP-PTC)", Space Nuclear Conference 2007, Boston, MA, June 24-28, 2007, Paper 2030

${ }^{3}$ Garber, A.E., Godfroy, T. "Design, Fabrication and Integration of a NaK-Cooled Circuit", ICAPP '06, Reno, NV, June 4-8, 2006, Paper 6331

${ }^{4}$ Penswick, B. "Liquid metal heater head / HX information", Memo Dated: 13 July 2007

${ }^{5}$ Penswick, B. "Liquid metal heater head modeling ", Memo Dated: 12 July 2007

${ }^{6}$ Dyson, R.W., Geng, S. M., Tew, R.C., Adelino, M. "Towards Multiphysics Analysis of Stirling Convertors", Engineering Applications of Computational Fluid Mechanics, 2008

${ }^{7}$ Oriti, S., Schreiber, J.G. "Design and Fabrication of a Stirling Thermal Vacuum Test", 2nd Int. Energy Conversion Engineering Conference, AIAA 2004-5561, 16-19 Aug. 2004, Providence, RI

${ }^{8}$ Gedeon, D., "Sage - Stirling-Cycle Model-Class Reference Guide", Version 4, Gedeon Associates, 2006

${ }^{9}$ Wood, J.G. "Actual Heat Flux Results", Memo, Aug. 2007

${ }^{10}$ Dyson, R.W., Wilson, S.D., Tew, R.C., Demko, R. "Fast Whole-Engine Stirling Analysis", 3rd Int. Energy Conversion Engineering Conference, AIAA 2005-5558, 15-18 Aug. 2005, San Francisco, CA

${ }^{11}$ Jiang, N., Simon, T. "Heat Transfer and Fluid Dynamics Measurements in the Expansion Space of a Stirling Cycle Engine", IMECE 2006-15631, NASA/CR-2006-214454, Dec. 2006

${ }^{12}$ Incropera, F. P., DeWitt, D.P. "Fundamentals of Heat and Mass Transfer", John Wiley \& Sons, 2002.

${ }^{13}$ Weisman, J., "Elements of Nuclear Reactor Design", Elsevier: New York, 1977

${ }^{14}$ Burdi, G.F. "SNAP Technology Handbook" Volume I, Liquid Metals, Atomic International Report No. NAA-SR-8617, August, 1964 


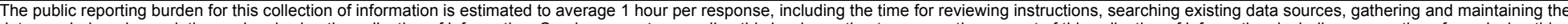

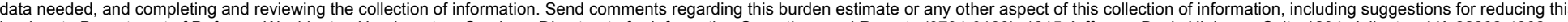

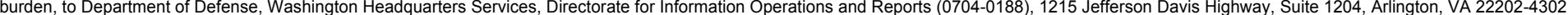

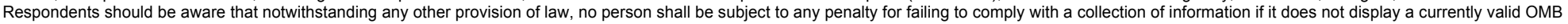
control number.

PLEASE DO NOT RETURN YOUR FORM TO THE ABOVE ADDRESS
1. REPORT DATE (DD-MM-YYYY)
2. REPORT TYPE
3. DATES COVERED (From - To)

01-03-2009

\section{TITLE AND SUBTITLE}

Technical Memorandum

Investigation of Liquid Metal Heat Exchanger Designs for Fission Surface Power

5b. GRANT NUMBER

5c. PROGRAM ELEMENT NUMBER

\section{AUTHOR(S)}

Dyson, Rodger, W.; Penswick, Barry; Robbie, Malcolm; Geng, Steven, M.

\section{5d. PROJECT NUMBER}

5e. TASK NUMBER

5f. WORK UNIT NUMBER

WBS 463169.02.03.02.01

\section{PERFORMING ORGANIZATION NAME(S) AND ADDRESS(ES)}

National Aeronautics and Space Administration

John H. Glenn Research Center at Lewis Field

8. PERFORMING ORGANIZATION

REPORT NUMBER

Cleveland, Ohio 44135-3191

E-16668

\section{SPONSORING/MONITORING AGENCY NAME(S) AND ADDRESS(ES)}

National Aeronautics and Space Administration

Washington, DC 20546-0001

10. SPONSORING/MONITORS
ACRONYM(S)
NASA; AIAA
11. SPONSORING/MONITORING
REPORT NUMBER
NASA/TM-2009-215505; AIAA-2008-
5733

\section{DISTRIBUTION/AVAILABILITY STATEMENT}

Unclassified-Unlimited

Subject Category: 20

Available electronically at http://gltrs.grc.nasa.gov

This publication is available from the NASA Center for AeroSpace Information, 301-621-0390

\section{SUPPLEMENTARY NOTES}

\section{ABSTRACT}

Fission surface power is an option for future Moon and Mars surface missions. High power nuclear reactor heated Stirling convertors are an option to provide reliable power for long duration outpost operations. This report investigates various design approaches for the liquid metal to acceptor heat exchange and clarifies the details used in the analysis.

\section{SUBJECT TERMS}

Stirling cycle power convertors; Fission surface power; Liquid metal heat; Thermal energy conversion

\begin{tabular}{|c|c|c|c|c|}
\hline \multicolumn{3}{|c|}{ 16. SECURITY CLASSIFICATION OF: } & \multirow{2}{*}{$\begin{array}{l}\text { 17. LIMITATION OF } \\
\text { ABSTRACT }\end{array}$} & \multirow{2}{*}{$\begin{array}{l}\text { 18. NUMBER } \\
\text { OF } \\
\text { PAGES } \\
22\end{array}$} \\
\hline $\begin{array}{l}\text { a. REPORT } \\
\mathrm{U}\end{array}$ & $\begin{array}{l}\text { b. ABSTRACT } \\
U\end{array}$ & $\begin{array}{l}\text { c. THIS } \\
\text { PAGE } \\
\text { U }\end{array}$ & & \\
\hline
\end{tabular}



